\title{
PROSPEK PENGEMBANGAN PLASMA NUTFAH IKAN BAUNG (Mystus nemurus C.V.)
}

\author{
Niam Muflikhah"), Syarifah Nurdawati ${ }^{\circ}$, dan Siti Nurul Aida \\ ") Peneliti pada Balai Riset Perikanan Perairan Umum, Mariana-Palembang
}

\begin{abstract}
ABSTRAK
Ikan baung (Mystus nemurus C.V.) termasuk ikan asli perairan umum yang mempunyai nilai ekonomi yang cukup tinggi dan layak untuk dibudidayakan, seperti halnya ikan-ikan perairan umum lainnya (jelawat, patin, lampam,tembakang, dan lain-lain). Ikan ini berpotensi untuk diekspor baik di tingkat konsumsi maupun di tingkat benih. Masalah yang dihadapi dalam budi daya adalah pertumbuhannya relatif lambat dibandingkan ikan patin, terutama pada saat air surut pada musim kemarau pertumbuhan sangat lambat bahkan minus dibandingkan pada saat air besar atau penghujan. Ikan baung bersifat karnivora tetapi sudah dapat tumbuh baik dengan pakan berbentuk pelet, baik komersil maupun racikan. Induk betina memiliki fekunditas yang tinggi dengan jumlah telur dari 2.500 sampai dengan 128.000 dari bobot 300 sampai dengan $1.250 \mathrm{~g}$, induk jantan juga memiliki sperma yang cukup banyak terutama di daerah Jambi dan Riau. Selain itu, memiliki ukuran yang relatif besar-besar dibanding ikan baung dari Sumatera Selatan (Palembang). Perbaikan mutu genetik ikan baung akan sangat berguna bagi pengembangan budi daya di masa yang akan datang.
\end{abstract}

KATA KUNCI: plasma nutfah, ikan baung, Mystus nemurus C.V.

\section{PENDAHULUAN}

Ikan baung merupakan ikan asli perairan umum, di daerah lain seperti di Wonogiri, Jawa Tengah dikenal sebagai ikan sogo, di Jawa Timur bernama ikan tagih, di Jawa Barat sebagai senggal, dan di Kalimantan ikan baung putih. Ikan ini di gemari oleh masyarakat pada umumnya, khususnya di Sumatera Selatan dan Jambi, karena berdaging tebal, sedikit berduri, dan memiliki rasa yang lezat. Memiliki nilai ekonomi yang penting karena nilai jual cukup tinggi, saat ini harga di pasaran Kota Palembang berkisar Rp.20.000,- per kg dalam bentuk ikan segar, dan menjadi lebih tinggi lagi dalam bentuk ikan asapan (salai) dengan harga Rp. 100.000,- per kg.

Produksi ikan baung dalam memenuhi permintaan pasar dan konsumen sampai dengan saat ini diperoleh dari hasil tangkapan di alam, baik untuk ukuran benih maupun ikan ukuran konsumsi. Hasil tangkapan sangat tergantung oleh beberapa faktor seperti kondisi perairan dan persediaan stok yang ada di alam. Selain itu, adanya kemungkinan perubahan lingkungan perairan sebagai akibat aktivitas manusia di sepanjang daerah aliran sungai seperti pemukiman, pertanian, transportasi, perindustrian, pembangkit tenaga listrik, dan rekreasi akan dapat mempengaruhi keberadaan, pola tingkah laku dan struktur populasi ikan.

Berdasarkan pada hasil pengamatan penulis di beberapa pasar dan informasi nelayan di Palembang ikan baung yang tertangkap saat ini mengalami penurunan baik ukuran maupun jumlahnya. Ikan yang berukuran 20 sampai dengan $25 \mathrm{~cm}$ dengan bobot 100 sampai dengan $200 \mathrm{~g}$, mendominasi di sebagian besar pasar kota Palembang $70 \%$, sedangkan ukuran 250 sampai dengan $400 \mathrm{~g}$ berkisar 20 sampai dengan
$30 \%$, dan 0 sampai dengan $5 \%$ ikan yang berukuran di atas $500 \mathrm{~g}$. Kenyataan ini menunjukkan bahwa populasinya mulai menurun. Bila kenyataan ini tidak mendapatkan perhatian yang serius, maka bukan sesuatu yang tidak mungkin bahwa ikan ini ke depan akan semakin langka dan akhirnya punah. Hal ini, menyebabkan kita akan kehilangan salah satu plasma nutfah di negeri ini.

\section{KLASIFIKASI DAN HABITAT}

Ikan baung mempunyai nama ilmiah Mystus nemurus C. V. sinonimnya Macrones nemurus C. V., merupakan anggota dari famili Bagridae dengan ordo Siluriformes. Ikan ini memiliki ciri-ciri sebagai berikut, bentuk badan panjang dan tidak bersisik, pada sirip dada terdapat tulang yang tajam dan bersengat, memiliki sirip lemak yang panjangnya kira-kira sama dengan panjang sirip dubur. Panjang total $5 \times$ tinggi atau 3 sampai dengan 3,5 kali panjang kepala (Djajadiredja et al., 1977). Selain sirip dada, sirip punggung berjari-jari keras dan berbisa, tulang rahang atas bergigi, warna bagian punggung agak kehitaman dan bagian dada putih (Bleeker et al.,1965). Ciri khas spesies ini adalah panjang dasar sirip lemak sama dengan panjang dasar sirip dubur, sungut hidung mencapai mata dan sungut rahang atas mencapai sirip dubur (Kottelat et al., 1993).

Penyebaran ikan baung di Indonesia meliputi Sumatera Barat, Jambi, Sumatera Selatan, Kalimantan, dan Jawa. Di daerah aliran Sungai Musi ditemukan mulai dari hulu sungai, Danau Ranau sampai dengan ke muara sungai dan perairan pasang surut (Gaffar, 1983).Di daerah aliran Sungai Batanghari dijumpai dari hulu sampai dengan ke hilir, dengan faktor kondisi yang terbaik terjadi di bulan 
April dan terjelek ditemukan pada bulan Oktober (Samuel et al., 1995). Di Kalimantan di temui di Sungai Barito (Prasetyo et al., 2004) dan di Riau dijumpai di Sungai Kampar (Husnah et al., 2003). Di negara lain ditemukan ikan baung seperti di Thailand, Malaka, dan Singapura (Mohsin \& Ambak, 1983) juga di Indochina (Kottelat et al., 1993).

Habitat ikan ini cukup luas, meliputi sungai-sungai besar, anak sungai, lubuk-lubuk sungai sampai dengan ke danau, terutama danau yang berada di dataran rendah, danau oxbow seperti danau teluk di Jambi, danau-danau rawa, rawa lebak (flood plain), hutan rawa, dan lain-lain. Pada musim hujan penyebaran ikan sampai dengan ke rawa lebak yang berhubungan langsung dengan sungai, sehingga kualitas air di lebak atau rawa kurang lebih sama dengan kualitas air sungai. $\mathrm{pH}$ air lebak atau rawa berkisar 5 sampai dengan 5,5 , sedangkan $\mathrm{pH}$ air sungai berkisar 5,5 sampai dengan 6,5. Di musim hujan hutan rawa banyak ditemukan mulai dari tingkat benih sampai dengan baung dewasa yang matang gonad, karena di tempat ini merupakan habitat mikroorganisme dan makroorganisme lain yang menjadi pakan alami bagi ikan baung (Utomo et al., 1992).

\section{REPRODUKSI}

Di alam ikan baung memijah pada awal musim penghujan. Di daerah aliran Sungai Batanghari, Jambi ikan baung betina yang matang gonad banyak diperoleh di bulan Oktober sampai dengan Januari, sedangkan induk jantan matang gonad pada bulan Nopember sampai dengan akhir Pebruari (Arsjad, 1973).

Secara morfologi, sangat mudah membedakan baung jantan dan betina. Pada ikan baung jantan terdapat papilla yang letaknya di belakang lubang genital, sedangkan pada ikan betina tidak ada. Demikian juga, untuk melihat induk yang matang gonad baik jantan maupun yang betina sangat mudah dikenal. Pada induk jantan papillanya berwarna merah yang dimulai dari ujung papilla menyebar ke arah pangkal papilla, bila tidak ada penampakan merah di papillanya, maka induk tersebut belum matang gonad (Gambar 1).

Sedangkan induk betina terlihat di bagian perut membesar karena mengandung telur, dan permukaan kulit sangat lembut bila diraba dan lubang genital membesar serta berwarna merah (Gambar 2).

Ukuran terkecil ikan baung yang matang kelamin adalah $32 \mathrm{~cm}$, namun pada ikan yang dipelihara di kolam dapat ditemukan ikan betina yang matang kelamin dengan ukuran $20 \mathrm{~cm}$ dan bobot $101 \mathrm{~g}$. Fekunditas induk betina yang bobotnya $327 \mathrm{~g} 20.815$ butir telur, sedangkan pada ikan yang bobotnya 1.584 g 87.118 butir. Ikan betina yang matang kelamin mempunyai indeks gonad somatik (ISG)=11-16\%, yang ditemukan pada bulan Desember sampai dengan Januari (Muflikhah et al., 1995). Warna telur yang belum matang putih kecoklatan atau kuning kecoklatan, sedangkan yang telah matang berwarna coklat tua atau coklat kemerahan.

Ukuran ikan baung jantan yang mulai matang kelamin adalah berkisar dari panjang 25 sampai dengan $30 \mathrm{~cm}$ dengan bobot antara 200 sampai dengan $250 \mathrm{~g}$. Sperma ikan baung berbentuk rumbairumbai. Menurut pengalaman dan pengamatan penulis sperma ikan baung yang matang kelamin (dengan melihat papillanya yang merah) yang berasal dari daerah aliran Sungai Musi ketika dibedah hanya $1 / 3$ sampai dengan $1 / 2$ bagian yang matang, ini nampak jelas dari warnanya yang berbeda yaitu, bagian yang mengarah ke saluran sperma berwarna putih susu, sedangkan bagian yang lain berwarna bening dan jernih. Berbeda dengan ikan baung yang

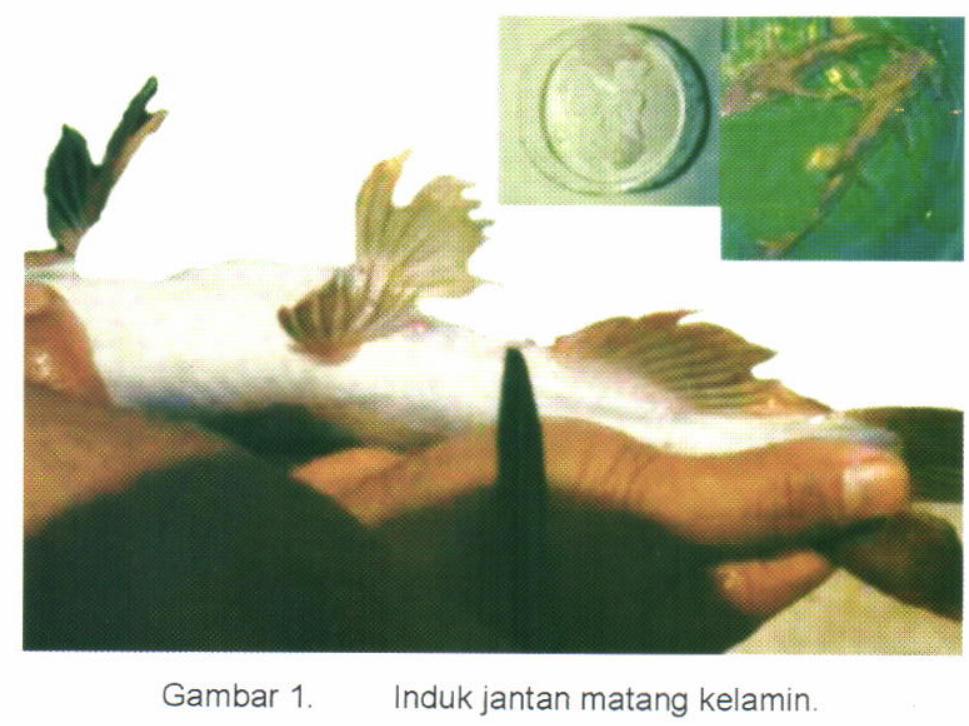




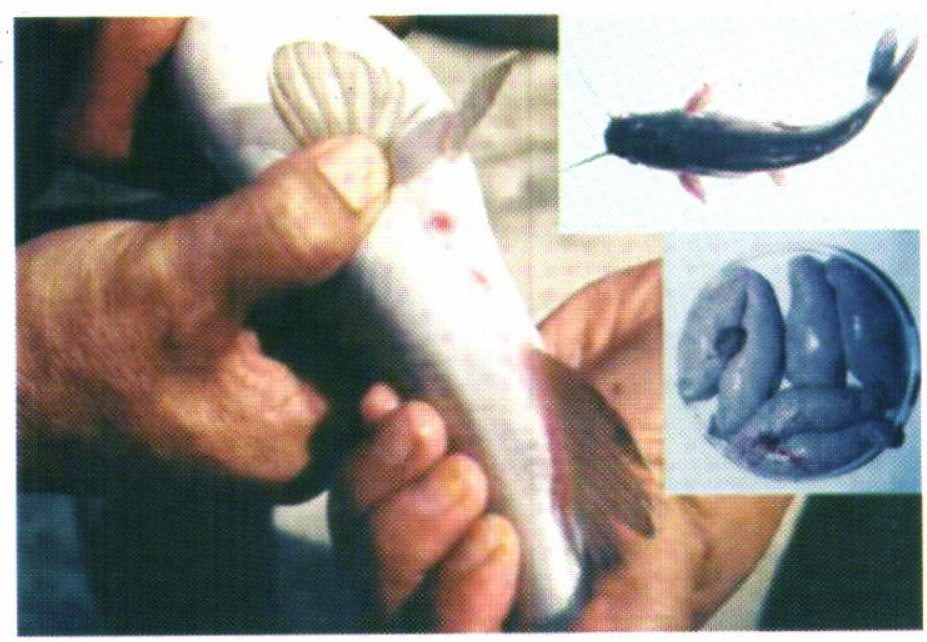

Gambar 2. Induk betina matang kelamin.

diperoleh dari daerah aliran Sungai Batanghari, Jambi yaitu di Muara Bungo. Induk jantan dengan penampakan yang sama papillanya setelah dibedah nampak sperma ikan baung secara keseluruhan semua berwarna putih susu tidak ada yang berwarna bening atau jernih.

Pemijahan di alam terjadi pada saat air meluap, ikan bermigrasi dari sungai ke genangan-genangan baru, di mana di lahan tersebut banyak persediaan pakan alami baik untuk larva, benih sampai dengan ke induk, terutama di hutan rawa, ini terlihat banyak ditemukan larva benih bahkan ikan remaja dan induk ikan baung dengan segala ukuran (Samuel et al., 1995; Utomo et al., 1992). Hal ini, serupa dengan pernyataan dari Shiraishi (1970) mengatakan bahwa ikan baung di Great Lake dan Quartre Bras memijah pada waktu air permukaan meluap. Lebih lanjut Arsjad (1973) mengatakan ikan baung di Jambi memijah 1 kali pada bulan Oktober sampai dengan Nopember dengan kenaikan air permukaan dan kecerahan air sebagai perangsang pemijahan. Menurut Ganapati, Alikunhi, \& Thivy dalam Qasim \& Qayum (1961) mengatakan bahwa untuk merangsang pemijahan keadaan tempat yang cocok lebih penting daripada keadaan kualitas fisika kimia air. Di India, ikan Mystus memijah di perairan yang berarus tenang dan berdasar lunak, habitat demikian merupakan tempat yang cocok untuk tempat pemijahan bagi Mystus (Saigal \& Motwani, 1961).

Percobaan pemijahan secara buatan telah dilakukan dengan teknik kawin rangsang (Gaffar \& Muflikhah, 1992). Hormon yang digunakan adalah hipofisa dari ikan mas atau ikan baung atau dikombinasikan dengan hormon HCG (Muflikhah et al., 1995). Dilakukan juga dengan menggunakan hormon ovaprim dosis $0,5 \mathrm{cc}$ per $\mathrm{kg}$ induk. Pembuahan dilakukan dalam baskom dengan menampung telur hasil stripping induk betina dan mencampur dengan sperma dari induk jantan, kemudian telur yang telah dibuahi diinkubasi dalam hapa yang diletakkan dalam bak fiber atau bak kayu yang dilapisi plastik, air yang digunakan adalah air perusahaan air minum yang telah diinapkan dan di aerasi. Penetasan terjadi 32 sampai dengan 36 jam kemudian, dan telur yang menetas mencapai $90 \%$ (Muflikhah et al., 2005).

\section{PAKAN DAN KEBIASAAN PAKAN}

Analisis isi lambung ikan sangat berguna untuk mengetahui pengembangan suatu jenis ikan, terutama ikan-ikan ekonomis penting agar dapat diambil langkah-langkah budi dayanya.

Ikan baung bersifat karnivor Vaas et al. (1953) mengatakan bahwa makanan ikan baung terdiri atas ikan, udang, insekta, dan larva. Hasil penelitian di India makanan marga Mystus pada umumnya terdiri atas ikan krustacea, insekta, sisa-sisa tumbuhan, dan detritus (Pandian, 1966; Saigal, 1964). Sedangkan menurut Arsjad (1973) udang merupakan pelengkap, pakan utamanya ikan dan insekta. Seperti yang disajikan dalam dalam Tabel 1, ikan menduduki kelompok pertama yang disukai oleh ikan baung yang terdapat di Danau Kenali dan Sipin Jambi. Demikian juga, ikan-ikan baung yang berasal dari Riau (Tabel 2).

Lebih lanjut Arsjad,(1973) mengatakan bahwa, susunan makanan anak ikan baung berbeda dengan ikan baung dewasa. Kelompok insekta merupakan bagian utama bagi anak ikan dibandingkan kelompok lainnya. Di bulan Pebruari anak-anak ikan memperlihatkan perubahan makanan yang cenderung mengarah seperti ikan dewasa, tetapi tidak demikian halnya dengan ikan jantan dan betina dewasa tidak mengalami perubahan susunan. Tetapi di bulan Januari ikan betina dan jantan dewasa mengalami perubahan susunan makanan yaitu ikan betina 
Tabel 1. Indek relatif penting makanan ikan baung di Danau Kenali dan Danau Sipin, Jambi

\begin{tabular}{|c|c|c|}
\hline \multicolumn{2}{|r|}{ 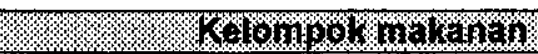 } & 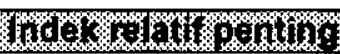 \\
\hline I. & Ikan & $3.676,1$ \\
\hline II. & Insekta & $2.611,6$ \\
\hline III. & Udang & 453,91 \\
\hline IV. & Nematoda & 302,26 \\
\hline V. & Annelida & 30,50 \\
\hline VI. & Lain-lain & - \\
\hline
\end{tabular}

Sumber/Sources: Arsjad, 1973

Tabel 2. Persentase indeks preponderen makanan ikan baung Mystus nemurus di wilayah tengah dan wilayah hilir perairan Sungai Kampar Riau

\begin{tabular}{|c|c|c|}
\hline \multirow{2}{*}{$8 \% 8 \% 10 \%$ \% } & \multicolumn{2}{|c|}{ 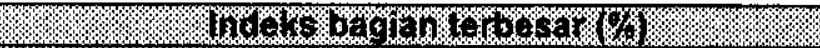 } \\
\hline & W1 $20 \% 1 \mathrm{~kg}$ & 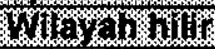 \\
\hline Ikan & 77,01 & 72,12 \\
\hline Udang & 17,98 & 20,59 \\
\hline Serangga air & 3,54 & 3,42 \\
\hline Potongan kayu & 0,60 & 0,85 \\
\hline Potongan tumbuhan & 0,08 & 0,42 \\
\hline Alga & 0,72 & 2,57 \\
\hline Tak teridentifikasi & 0,03 & 0 \\
\hline Jumlah total & $99,96 \%$ & $99,97 \%$ \\
\hline
\end{tabular}

Sumber/Sources: Anggraini, 2004

dewasa bagian terbesar pakan utama adalah ikan, sedangkan ikan jantan dewasa pakan utamanya kelompok insekta. Ketika udang banyak ditemukan yaitu pada bulan Oktober udang merupakan pakan utama, tetapi di bulan berikutnya sejalan dengan menurunnya populasi udang, maka ikan baung kembali ke pakan utamanya yaitu ikan atau insekta Tabel 3 menyajikan jenis-jenis organisme yang terdapat dalam usus ikan baung.

Adanya perubahan susunan makanan lebih disebabkan oleh perubahan jumlah jasad makanan dalam perairan. Selain itu, perbedaan posisi rantai makanan juga karena adanya perbedaan habitat (Odum dalam Steele, 1970).

Perbedaan pakan antara ikan kecil dan dewasa baung lebih disebabkan oleh bukaan mulutnya. Menurut Nikolsky (1963) perbedaan tersebut disebabkan oleh proses adaptasi terhadap pencernaan dan perubahan komposisi enzim yang disesuaikan oleh kebutuhan. Selanjutnya Lagler (1962) mengatakan, organisme yang dimakan disesuaikan dengan perkembangan pencernaannya. Hal ini, didukung oleh hasil penelitian bahwa larva ikan baung yang diberi pakan infusoria selama 3 sampai dengan 4 hari kemudian diberi pakan artemia sampai dengan umur 21 hari lebih baik pertumbuhannya daripada postlarva yang diberi pakan infusoria selama 15 hari (Muflikhah, 2002).

\section{PROSPEK PENGEMBANGAN}

Ikan baung yang berasal dari daerah aliran Sungai di Sumatera, Kalimantan, dan Jawa memiliki prospek pengembangan yang cukup baik. Selain keunggulan pada sifat-sifat biologi seperti memiliki ukuran yang cukup besar, fekunditas yang cukup tinggi, harga jual yang cukup mahal, dan memiliki nilai ekspor, karena ada permintaan dari negara tetangga seperti Malaysia dan Singapura baik di tingkat benih, maupun ukuran konsumsi

Ikan baung telah didomestikasi dan tumbuh baik dengan pemberian pakan pelet komersil (Gaffar, 1983). Dan tumbuh baik oi kolam stagnan (Muflikhah \& Gaffar, 1992), bahkan di kolam rawa (Muflikhah \& Aida, 1995). Sehingga dapat hidup di berbagai tipe perairan seperti danau, genangan-genangan air yang timbul secara periodik, rawa, dan lebak (pada musim hujan). Beberapa pertambahan bobot ikan baung dengan pemberian pakan pelet disajikan dalam Tabel 4

Ukuran ikan konsumsi mulai 300 sampai dengan $1.000 \mathrm{~g}$. Dalam pemeliharaan di sangkar, ukuran 20 sampai dengan $300 \mathrm{~g}$ dapat dicapai dalam waktu 1 tahun dengan pemberian pelet komersil dan secara periodik ditambah ikan rucah. Pertambahan bobot ikan baung relatif lambat, namun dengan pemberian ikan rucah memberikan pertumbuhan yang meningkat. Dari beberapa informasi nelayan di Ogan llir, Sumatera Selatan yang juga melakukan usaha budi daya terutama ikan baung jauh lebih menguntungkan daripada ikan patin (Rp.7000,sampai dengan Rp.9000,- per $\mathrm{kg}$ ), karena harga jual lebih tinggi dibanding ikan patin yaitu berkisar Rp. 20.000, - per kg) (Tabel 5). Selain itu, pakan yang diberikan berupa campuran dedak dan ikan rucah yang banyak diperoleh di daerah setempat. 
Tabel 3. Jenis-jenis organisme yang terdapat dalam usus ikan baung

\begin{tabular}{|c|c|c|c|}
\hline \multirow{2}{*}{ kelompor. } & \multicolumn{3}{|c|}{ Macam Iasad } \\
\hline & 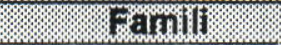 & Spesess & Tama lokar \\
\hline \multirow[t]{12}{*}{ Ikan } & Cyprinidae & Puntius nini & serepang \\
\hline & & P. schwanofeldi & lampam \\
\hline & & P.tetrazona & langli \\
\hline & & Osteocheilus triporus & aro \\
\hline & & Hampala ampolong & sebaro lalat \\
\hline & & Rasborichthys helfrichi & seluang gunting \\
\hline & & Rasbora kalocrhome & seluang \\
\hline & & Thynnichthys thynnoides & ringo \\
\hline & & Crossochilus oblongus & seluang putih \\
\hline & Anabantidae & Anabas testudineus & betok \\
\hline & & Pristolepis fasciatus & beterung \\
\hline & Mastacembelidae & Mastacembelus sp. & tilan \\
\hline \multirow[t]{20}{*}{ Insekta } & Ephemeroptera & Isonychia & \\
\hline & Odonata & Dorocordulia & \\
\hline & & $\begin{array}{l}\text { Leocorrhinia } \\
\text { Pantala }\end{array}$ & \\
\hline & & Ichunuria & \\
\hline & & Helocordulia & \\
\hline & Hemiptera & Corixid & \\
\hline & & Ranatra & \\
\hline & Neuroptera & Climacia & \\
\hline & Trichoptera & Hydropsyche & \\
\hline & & Limnephilus & \\
\hline & & Helicopsyche & \\
\hline & & Philotamus & \\
\hline & Coleoptera & Acilius & \\
\hline & & Hydroporus & \\
\hline & Diptera & $\begin{array}{l}\text { Chaoborus } \\
\text { Pentaneura }\end{array}$ & \\
\hline & & Palpomya & \\
\hline & & Tipula & \\
\hline & & Chironomus & \\
\hline & & Culex & \\
\hline & & Pericoma & \\
\hline Crustacea & & Macrobrachium & Udang \\
\hline Nematoda & & Alaimus & \\
\hline Annelida & \multirow{2}{*}{\multicolumn{3}{|c|}{$\begin{array}{l}\text { Lumbricidae } \\
\text { Bagian-bagian kepiting, kepah, rumput-rumputan, daun, ranting, ganggang hijau Spirogyra, } \\
\text { dan detritus }\end{array}$}} \\
\hline Lain-lain & & & \\
\hline
\end{tabular}

Tabel 4. Pertambahan bobot ikan baung dengan pakan pelet

\begin{tabular}{|c|c|c|c|}
\hline \multirow{2}{*}{ Trpe budi daya } & \multicolumn{2}{|c|}{ Pakan yang diberikan } & \multirow{2}{*}{, } \\
\hline & . pelet & TKan r ram & \\
\hline Sangkar* & Komersil & - & $80 \mathrm{~g}$ per $130 \mathrm{hr}$ per ind. \\
\hline Sangkar** & Komersil & - & \\
\hline Kolam stagnan & Komersil & - & $66,27 \mathrm{~g}$ per $90 \mathrm{hr}$ per ind. \\
\hline Kolam rawa Patratani, ( $\mathrm{pH} 5,5-6,5^{\text {****}}$ & Racikan & $\begin{array}{l}\text { seminggu } \\
\text { sekali }\end{array}$ & $\begin{array}{l}170,3 \mathrm{~g} \text { per } 120 \mathrm{hr} \text { per } \\
\text { ind. }\end{array}$ \\
\hline 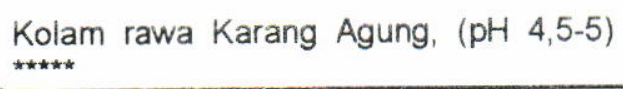 & Komersil & - & $67 \mathrm{~g}$ per $150 \mathrm{hr}$ per ind. \\
\hline
\end{tabular}


Tabel 5. Jumlah dan harga ikan baung rata-rata di beberapa pasar Kota Palembang, tahun 2004

\begin{tabular}{|c|c|c|c|c|}
\hline P4aro & 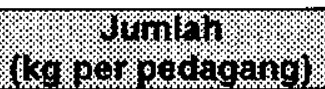 & 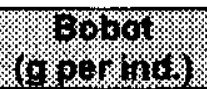 & (c) & $4=196 \%$ \\
\hline Palimo & $3-7$ & $100-300$ & $20.000,-$ & $\begin{array}{l}\text { Pangkalan Balai } \\
\text { Sp.Padang }\end{array}$ \\
\hline $\begin{array}{l}\text { Cinde } \\
16 \text { illir }\end{array}$ & $\begin{array}{l}1 \cdot 3 \\
5-8\end{array}$ & $\begin{array}{l}300-700 \\
100-800\end{array}$ & $\begin{array}{l}22.000,- \\
20.000,-\end{array}$ & $\begin{array}{l}\text { Hulu Sungai Musi } \\
\text { Sp.Padang }\end{array}$ \\
\hline Plaju & $3-5$ & $100-500$ & 20.000 ,- & Hulu Sungai Musi \\
\hline Kertapati & $2-4$ & $150-400$ & 19.000,- & Hulu Sungai Musi \\
\hline Tangga buntung & $2-5$ & $100-600$ & 19.000,- & \\
\hline
\end{tabular}

Sumber/Sources: Wawancara dengan pedagang setempat

Di alam ikan baung dapat mencapai ukuran 1 sampai dengan $2 \mathrm{~kg}$, namun kini sulit ditemukan untuk ukuran tersebut di pasar tradisional (Tabel 5). Menurunnya jumlah dan ukuran ikan baung di pasaran yang berasal dari tangkapan di alam, memberikan peluang untuk segera melakukan usaha budi daya untuk pengembangannya, dan restocking di alam serta konservasi habitat untuk mempertahankan populasinya

Masalah yang dihadapi dalam melakukan budi daya ikan baung adalah ikan baung membutuhkan air yang cukup banyak dalam pemeliharaannya yaitu sekitar 0,75 m dari dasar kolam. Demikian juga, di sangkar terdapat korelasi antara musim kemarau dan musim hujan. Di bulan Agustus sampai dengan Oktober pertumbuhan ikan baung lambat karena debet air Sungai Komering kecil dan musim hujan di bulan Nopember sampai dengan Januari pertumbuhan lebih cepat (Asyari \& Muflikhah, 1994). Kenyataan ini juga didukung oleh hasil penelitian pertumbuhan ikan baung yang di alam di bulan Juli sampai dengan September pertumbuhan lambat dan bulan Nopember sampai dengan Maret pertumbuhan lebih cepat (Anonim, 1997). Selain itu, pertumbuhan lambat juga karena pakan pelet komersial yang diberikan kurang mendukung pertumbuhan yang cepat.

Untuk memulai budi daya ikan baung, pengadaan benih unggul dapat ditempuh melalui perbaikan mutu genetik yang secara umum dapat dilakukan dengan penangkaran selektif dan persilangan inter spesies atau kombinasi ke-2. Pengumpulan atau koleksi induk dari berbagai penyebaran geografis memungkinkan didapatkan induk-induk dengan heterozygotis tinggi Potensi ini memungkinkan karena dari pengamatan penulis di beberapa lokasi di luar Palembang seperti Jambi dan Riau, misalnya secara umum ikan memiliki ukuran lebih besar dengan bobot lebih dari $1 \mathrm{~kg}$ bahkan mencapai 2 sampai dengan $3 \mathrm{~kg}$. Ikan baung jantan yang matang kelamin memiliki sperma secara keseluruhan matang kelamin, sedangkan di Palembang hanya 30 sampai dengan $50 \%$ yang matang kelamin. Dan induk betina memiliki fekunditas yang tinggi yaitu 2.500 sampai dengan 123.000 butir (Arsjad, 1973); Muflikhah et al. (1995) berkisar dari 34.701 sampai dengan 87.118 butir dengan kisaran bobot ikan 735,0 sampai dengan $1.584,3 \mathrm{~g}$

\section{KESIMPULAN}

1. Ikan baung termasuk ikan perairan umum yang diperdagangkan sebagai ikan konsumsi dan berpotensi sebagai ikan ekspor.

2. Keunggulan ikan baung dengan ikan lain adalah penyebaran serta adaptasinya cukup luas, sifat pakan di alam karnivora ternyata mampu tumbuh baik dengan pakan pelet atau racikan, selain itu ikan betina memiliki fekunditas yang tinggi dan induk jantan di beberapa tempat memiliki sperma yang cukup banyak.

3. Perbaikan mutu genetik akan sangat berguna untuk menunjang pengembangan budi daya ikan di masa mendatang

\section{DAFTAR PUSTAKA}

Anggraini, D. 2004. Kebiasaan makan ikan baung (Mystus nemurus C. V.) di Sungai Kampar. Propinsi Riau. Skripsi. Jurusan Biologi Fakultas MIPA. Universitas Sriwijaya. Palembang. 37 hal.

Anonim. 1977. Biologi ikan lebak lebung Indonesia. Implikasinya untuk Pengelolaan Perikanan Sungai. Work Shoop Pusat Penelitian dan Pengembangan Perikanan/MRAG. Tanggal 10 Juni 1997. MRAG. Ltd. UK. Pusat Penelitian dan Pengembangan Perikanan Indonesia. Universitas Pertanian Bangladesh My Mensingh. Bangladesh.

Arsjad, M. N. 1973. Perkembangbiakan, kebiasaan makanan, dan hubungan panjang bobot dan faktor kondisi ikan baung (Mystus nemurus $C$. V.) di Danau Sipin dan Danau Kenali Jambi. Thesis. Institut Pertanian Bogor. Bogor. 83 hal.

Asyari, N. \& Muflikah. 1994. Pembesaran ikan baung (Mystus nemurus C.V.) di dalam sangkar. Laporan Penelitian Sub Balai Penelitian Perikanan Air Tawar. Palembang. 7 hal.

Bleeker, P. M., Weber, \& F. de Beaufort. 1965. The fishes of the Indo-Australian archipelago. Vol.Il. $E$ J. Brill. Leiden. 404 hal. 
Dadiek, P. Asyari, \& A. Sudradjad. 2004. Inventarisasi dan karakterisasi habitat perairan daerah aliran Sungai Barito. Prosiding Seminar Hasil. Riset Pusat Riset Perikanan Tangkap. Jakarta.

Djajadiredja, R., S. Hatimah, \& Z. Arifin. 1977. Buku pedoman pengenalan sumber perikanan darat bagian I (Jenis-jenis ikan ekonomis penting) Direktorat Jenderal Perikanan Departemen Pertanian. Jakarta.

Gaffar, A. K. 1983. Percobaan pembesaran ikan baung (Macrones nemurus C.V.) di dalam sangkar dengan perlakuan formula pakan. Buletin Penelitian Perikanan Darat. 3 (2): 5-12.

Gaffar, A., K. \& N. Muflikah. 1992. Penelitian budi daya ikan baung. Prosiding Hasil Penelitian Perikanan Air Tawar 1991/1992. Balai Penelitian Perikanan Air Tawar. Bogor.

Husnah, S. N. Aida, \& S. Gautama. 2003. Riset jumlah, jenis, penyebaran, dan peran ikan budi daya terlepas terhadap hasil tangkapan ikan di perairan umum. Laporan Akhir Proyek Penguasaan Teknologi Perikanan. Balai Riset Perikanan Perairan Umum. Badan Riset Kelautan dan Perikanan. Departemen Kelautan dan Perikanan. 19 hal.

Kottelat, M., A. J. Whitten, S. N. Kartikasari, \& S. Wirjoatmodjo. 1993. Fresh water fishes of Western Indonesia and Sulawesi. Berkeley Books Pte. Ltd Forrer Road. P. O. Box 115. Singapura 9128.

Lagler, K. F., C. E. Bardach, R. R. Miller. 1962. Ichthyology. John Willey and Sons. Inc New York London Toppan Company Ltd. Tokyo Japan.

Mohsin, A. K. M. \& A. M. Ambak 1983. Freshwater fishes of peninsular Malaysia. Penerbit University Pertanian Malaysia.

Muflikhah, N. \& A. K.Gaffar. 1992. Pengaruh perbedaan padat tebar terhadap pertumbuhan ikan baung (Mystus nemurus C.V.) di kolam stagnan. Buletin Penelitian Perikanan Darat. 2 (2) 129-133.

Muflikhah, N., Yosmaniar, A. K. Gaffar, \& M. Jahri. 1995. Pengamatan fekunditas ikan baung (Mystus nemurus C. V.) yang dipelihara dalam kolam. Kumpulan Makalah Seminar Penyusunan Pengolahan Hasil Penelitian Perikanan di Perairan Umum. SBPPAT. BPPAT. Pusat Penelitian dan Pengembangan Perikanan. Badan Penelitian dan Pengembangan Pertanian. Departemen Pertanian. Hal: 136-139.

Muflikhah, N. \& S. N. Aida. 1995. Pengaruh perbedaan jenis pakan terhadap pertumbuhan ikan baung
(Mystus nemurus C. V.) di kolam rawa. Kumpulan Makalah Seminar Penyusunan Pengolahan Hasil Penelitian Perikanan di Perairan Umum. SBPPAT. BPPAT. Penelitian dan Pengembangan Perikanan. Badan Penelitian dan Pengembangan Pertanian. Departemen Pertanian. Hal: 155-158.

Muflikhah, N. 2002. Pemanfaatan infusoria untuk meningkatkan kelangsungan hidup larva ikan. Prosiding 2 Aplikasi Biologi dalam Peningkatan Kesejahteraan Manusia dan Kualitas Lingkungan. Seminar Nasional. Fakultas Biologi Universitas Gadjah Mada. p 204-212.

Muflikhah, N., S. Nurdawati, \& S. N. Aida. 2005. Pengaruh pakan yang berbeda terhadap pematangan gonad ikan baung (Mystus nemurus C.V.) dalam karamba, kualitas telur, dan sintasan larva. Jurnal Perikanan (J. Fish. Sci.). VII (1): 1 10.

Muflikah, N. 2005. Pertumbuhan dan sintasan ikan baung (Mystus nemurus $\mathrm{C}$. V.) pada berbagai tingkat tebar di kolam lahan pasang surut dan perbandingan pertumbuhannya di beberapa media. Prosiding Seminar Nasional Perikanan Indonesia 2005 Jilid 1. Sekolah Tinggi Perikanan. Jakarta. Hal: 304-312

Nikolsky, G. V. 1963. The ecology of fishes. Academic Press. London and New York. 352 pp.

Qasim, S. Z. \& A. Qayyum. 1961. Spawning frequencies and breeding season of some fresh water fishes with special reference to those occuring in the plain of Northern India. Indian Journal Fisheries. 8(1): 24-43.

Pandian, T. J. 1966. Feeding and reproductive cyclus of the fish Mystus gulio in the cooum back water Madras. Indian Journal Fisheries. 13 (1 \& 2): 322 333.

Saigal, B. N. \& M. P.Motwani. 1961. Studies on the fishery and biology of the comercial cat fishes of the ganga river system. I Early Live History, Bionomic, and Breeding of Mystus (osteophagus) senghala (Sykes). Indian Journal Fisheries. 8 (1): 60-74.

Saigal, B. N. 1964. Biology of the commercial cat fishes of the ganga river sistem I. Maturity, Spawning, and Food of Mystus (osteobagrus) aor (Hamilton). Indian Journal Fisheries. Sect. A. 11 (1): $1-44$

Samuel \& A. Said.1995. Hubungan panjang bobot dan faktor kondisi ikan baung (Mystus nemurus C. V.) di daerah aliran Sungai Batanghari, Jambi. Kumpulan Makalah Seminar Penyusunan Pengolahan Hasil Penelitian Perikanan di Perairan Umum. SBPPAT. BPPAT. Penelitian dan 
Pengembangan Perikanan. Badan Penelitian dan Pengembangan Pertanian. Departemen Pertanian. Hal: 127-130.

Shiraishi, Y. 1970. The migration of fishes in the mekong river. $\mathrm{p}$ 135-140. Proccidding int. Biol. Prog. Sect. P. F. Unesco Field Science Office for South East Asia. Jakarta.

Steele, J. H.1970. Marine food chains. Univ. Calif. Press. 552 pp.
Utomo, A. D., Z. Nasution, \& S. Adjie. 1992. Kondisi ekologi dan potensi sumber daya perikanan sungai dan rawa. Prosiding Temu Karya IImiah Perikanan Perairan Umum. Palembang.

Vaas, K. F., M. Sahian, \& G. Wiraatmadja. 1953. On the ecology and fisheries of some inland waters along the rivers Ogan and Komring in South East Sumatera. Cont. Inl. Fish. Res. Sta. Jakarta (3): 1. 31. 